\title{
Contents Vol. 28, 1998
}

Haemostasis

No. 1

Original Papers

1 A Characterization of the Coagulant and Fibrinolytic Profile of Human Pancreatic Carcinoma Cells Kakkar, A.K.; Chinswangwatanakul, V.; Tebbutt, S.; Lemoine, N.R.; Williamson, R.C.N. (London)

7 Profiles of Plasma Serpins in Patients with Advanced Malignant Melanoma, Gastric Cancer and Breast Cancer

Wojtukiewicz, M.Z.; Ruciñska, M.; Kloczko, J.; Dib, A. Galar, M. (Bialystok)

14 Multiple Intracranial Hemorrhages at the Time of a Transiently Prolonged Activated Partial

Thromboplastin Time in an Infant with Congenital Factor VII Deficiency

Erduran, E.; Mocan, H.; Aslan, Y.; Sari, A. (Trabzon)

17 High Doses of Methylene Blue/Light Treatment Crosslink the A-Alpha-Subunit of Fibrinogen: Influence of this Photooxidization on Fibrinogen Binding to Platelets

Lorenz, M.; Müller, M.; Jablonka, B.; Vigh, T.

(Frankfurt/Main); Kirchmaier, C.M.'(Wiesbaden)

25 Recurrent Warfarin-Induced Skin Necrosis in Kindreds with Protein S Deficiency Sallah, S.; Abdallah, J.M.; Gagnon, G.A. (Greenville, N.C.)

31 Circulating Activated Protein $\mathrm{C}$ in Subjects with Heterozygous GIn506-Factor V

Petäjä, J. (La Jolla, Calif./Helsinki); Hakala, L.; Rasi, V (Helsinki); Griffin, J.H. (La Jolla, Calif.)

37 Reactivity of Platelets from Healthy Individuals and from Patients with Hematologic Diseases following Incubation with Pegylated Recombinant Human Megakaryocyte Growth and Development Factor in vitro

Matzdorff, A.C.; Kemkes-Matthes, B.; Pralle, H. (Giessen)

45 Effects of a Supersulfated Low Molecular Weight Heparin (IK-SSH) on Different Hemostatic Parameters

Glusa, E. (Jena); Barthel, W. (Erfurt); Schenk, J.; Radziwon, P. (Frankfurt/Main); Butti, A. (Milan); Markwardt, F ; Breddin, K.H. (Frankfurt/Main)

13 Announcement
No. 2

Original Papers

57 Low-Dose Vitamin $K_{1}$ versus Short-Term Withholding of Acenocoumarol in the Treatment of Excessive Anticoagulation Episodes Induced by Acenocoumarol. A Retrospective Comparative Study

Ortín, M.; Olalla, J.-I.; Marco, F.; Velasco, N. (Torrelavega)

62 Randomized Assessment of a Warfarin Nomogram for Initial Oral Anticoagulation after Venous Thromboembolic Disease

Kovacs, M.J.; Cruickshank, M. (London, Ont.); Wells, P.S (Ottawa); Kim, H.; Chin-Yee, I.; Morrow, B.; Boyle, E.; Kovacs, J. (London, Ont.)

70 Early versus Delayed Introduction of Oral Vitamin K Antagonists in Combination with Low-Molecular-

Weight Heparin in the Treatment of Deep Vein

Thrombosis. A Randomized Clinical Trial

Leroyer, C.; Bressollette, L.; Oger, E.; Mansourati, J.;

Chèze-Le Rest, C.; Nonent, M. (Brest); Buchmuller, A.; Tardy, B.; Decousus, H. (Saint-Etienne); Parent, F.; Simonneau, G. (Clamart); Juste, K.; Ill, P. (Montrouge); Abgrall, J.F.; Clavier, J.; Mottier, D. (Brest); for the ANTENOX Study Group

78 Enoxaparin Reduces Cerebral Edema after Photothrombotic Injury in the Rat Pratt, J.; Boudeau, P.; Uzan, A.; Imperato, A.; Stutzmann, J.-M. (Vitry-sur-Seine)

86 Effects of Polysulfonate Derivative (GL 522-Y-1) on Coagulation in vitro and Thrombosis in vivo

Radziwon, P.; Boczkowska-Radziwon, B.; Giedrojc, J. (Białystok); Schenk, J.(Homburg/Saar); Wojtukiewicz, M.Z; Kloczko, J. (Białystok); Breddin, H.K. (Frankfurt am Main)

93 Activated Recombinant Human Coagulation Factor VII Therapy for Intracranial Hemorrhage in Patients with Hemophilia A or B with Inhibitors. Results of the NovoSeven Emergency-Use Program Arkin, S. (New York, N.Y.); Cooper, H.A. (Chapel Hill, N.C.); Hutter, J.J. (Tucson, Ariz.); Miller, S. (Brooklyn, N.Y.); Schmidt, M.L. (Urbana, Ill.); Seibel, N.L. (Washington, D.C.); Shapiro, A. (Indianapolis, Ind.); Warrier, I. (Detroit, Mich.)

99 Increase in Thrombin Generation after Coronary Thrombolysis with rt-PA or Streptokinase with Simultaneous Heparin versus Heparin Alone Réganon, E.; Ferrando, F.; Vila, V.; Villa, P.; Martínez-Sales, V.; Fayos, L.; Ruano, M.; Aznar, J. (Valencia)

106 Influence of HIV-Infection on the Karnofsky Score and General Social Functioning in Patients with Hemophilia

Wenzel, T. (Vienna); Pindur, G.; Mörsdorf, S.; Giacchi, J. Homburg/Saar)

\section{KARGER}

Fax + 41613061234 E-Mail karger@karger.ch www.karger.com (c) 1998/99 S. Karger AG, Basel

Access to full text and tables of contents, including tentative ones for forthcoming issues: www.karger.com/journals/hae/hae bk.htm 
No. 3-4

Vascular Factors in Dementia

Haverkate, F. (Leiden)

114 Introduction

Kluft, C. (Leiden); Koudstaal, P.J.; Grobbee, D.E. (Rotterdam)

Epidemiology of Dementia

117 The New Epidemic: Frequency of Dementia in the Rotterdam Study

Breteler, M.M.B.; Ott, A.; Hofman, A. (Rotterdam)

124 Epidemiology of Post-Stroke Dementia von Kooten, F.; Koudstaal, P.J. (Rotterdam)

134 Epidemiology of Vascular Dementia Leys, D.; Pasquier, F. (Lille); Parnetti, L. (Perugia)

Diagnosis of Dementia

151 Diagnostic Criteria for Vascular Dementia Scheltens, Ph.; Hijdra, A.H. (Amsterdam)

158 Value of Screening Instruments in the Diagnosis of Post-Stroke Dementia

de Koning, I.; van Kooten, F.; Koudstaal, P.J. (Rotterdam)

Vascular Factors in Dementia

167 Risk Factors for Vascular Disease and Dementia Breteler, M.M.B. (Rotterdam); Bots, M.L. (Rotterdam/Utrecht); Ott, A.; Hofman, A. (Rotterdam)

174 Possible Link between Lipid Metabolism and Cerebral Amyloid Angiopathy in Alzheimer's Disease: A Role for High-Density Lipoproteins? Mulder, M.; Terwel, D. (Maastricht)

195 Role of APOE in Dementia: A Critical Reappraisal de Knijff, P. (Leiden); van Duijn, C.M. (Rotterdam)

202 Role of Platelet Activation in Dementia van Kooten, F. (Rotterdam); Ciabattoni, G. (Rome); Patrono, C. (Chieti); Koudstaal, P.J. (Rotterdam)

209 Response to Activated Protein C in Subjects with and without Dementia. The Dutch Vascular Factors in Dementia Study

Bots, M.L. (Rotterdam/Utrecht); van Kooten, F

Breteler, M.M.B. (Rotterdam); Slagboom, P.E.; Hofman, A.

Haverkate, F.; Meijer, P. (Leiden); Koudstaal, P.J.

(Rotterdam); Grobbee, D.E. (Utrecht); Kluft, C. (Leiden)

216 Coagulation and Fibrinolysis Markers and Risk of

Dementia. The Dutch Vascular Factors in Dementia Study

Bots, M.L. (Rotterdam/Utrecht); Breteler, M.M.B.;

van Kooten, F. (Rotterdam); Haverkate, F.; Meijer, P. (Leiden); Koudstaal, P.J. (Rotterdam); Grobbee, D.E. (Utrecht); Kluft, C. (Leiden)

223 Specificity of Haemostasis Abnormalities for Vascular Phenotypes

Lowe, G.D.O. (Glasgow); Haverkate, F. (Leiden)

228 Author Index

228 Subject Index
No. 5

Original Papers

229 Efficacy of Unfractionated Heparin, Low Molecular Weight Heparin and Both Combined for Releasing Total and Free Tissue Factor Pathway Inhibitor Altman, R.; Scazziota, A.; Rouvier, J. (Buenos Aires)

236 Secondary Prevention of Venous Thromboembolism: A Role for Low-Molecular-Weight Heparin Monreal, M.; Roncales, F.J.; Ruiz, J.; Muchart, J.; Fraile, M.; Costa, J.; Hernandez, J.A. (Badalona)

244 Antibodies against Factor VIII in Patients with Solid Tumors: Successful Treatment of Cancer May Suppress Inhibitor Formation Sallah, S. (Memphis, Tenn.); Singh, P.; Hanrahan, L.R (Greenville, N.C.)

250 Massive Intracranial Bleeding Requiring Emergency Splenectomy in a Patient with CMV-Associated Thrombocytopenia

Gural, A.; Gillis, S.; Gafanovich, A.; Israel, Z.; Wolf, D.; Pomeranz, S.; Ben-Yehuda, D. (Jerusalem)

256 High-Dose Dexamethasone for Splenectomy in Patients with Idiopathic Thrombocytopenic Purpura Bulvik, S. (Tel Aviv/Netanya); Winder, A.; Ben-Tal, O.; Szold, A.; Eldor, A. (Tel Aviv)

260 Adenosine 5'-Diphosphate-Induced Platelet Aggregation in Uremia Shows Resistance to Inhibition by the Novel Nitric Oxide Donor GEA 3175 but Not by S-Nitroso-N-Acetylpenicillamine Whiss, P.A.; Larsson, R. (Linköping)

268 Relation between Carotid Intima-Media Thickness Platelet Surface Activation and Endothelial Cell Markers

Ramsis, N.; El-Hawary, A.A.; Ismail, E. (Ismailia)

Letter to the Editor

276 Prevalence of Arg306 Mutation of the Factor V Gene in Korean Patients with Thrombosis

Song, K.S.; Park, Y.S.; Kim, H.K.; Choi, J.R.; Park, Q. (Seoul) 
No. 6

Original Papers

277 Relative and Absolute Changes of Activated Platelets, Microparticles and Platelet Aggregates after Activation in vitro

Matzdorff, A.C.; Berchner, D.; Kühnel, G.;

Kemkes-Matthes, B.; Pralle, H.; Voss, R. (Giessen)

289 The Procoagulant Effect of Thrombin on

Fibrin(ogen)-Bound Platelets

Sanders, M.W.; Nieuwenhuys, C.M.A.; Feijge, M.A.H

(Maastricht); Rook, M. (Utrecht); Béguin, S.;

Heemskerk, J.W.M. (Maastricht)

301 Elevated Thrombotic Activity after Myocardial Infarction: A 2-Year Follow-Up Study

Martínez-Sales, V.; Vila, V.; Réganon, E.; Goberna, M.A.; Ferrando, F.; Palencia, M.A.; Aznar, J. (Valencia)

307 Glycemic Control and Coagulation Inhibitors in Diabetic Patients

Altunbas, H.; Karayalçin, Ü.; Ündar, L. (Antalya)

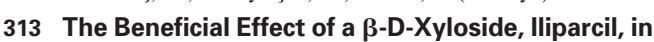
the Prevention of Postthrombolytic Rethrombosis in the Rat

Chicaud, P.; Rademakers, J.R.; Millet, J. (Daix)

321 Comparative Study of a Portable Monitor for

Prothrombin Time Determination, Coaguchek ${ }^{\circledR}$, with Three Systems for Control of Oral

Anticoagulant Treatment

Vacas, M.; Lafuente, P.J.; Cuesta, S.; Iriarte, J.A. (Bilbao)

320 Book Review

329 Author Index Vol. 28, 1998

331 Subject Index Vol. 28, 1998
Suppl. 1

A Guide to Oral Anticoagulant Therapy Federazione Centri Sorveglianza Anticoagulati (FCSA)

Edited by: Coccheri, S. (Bologna)

Suppl. 2

15th International Congress on Thrombosis

Antalya, Turkey, October 16-21, 1998

Abstracts

Editors: Balkuv-Ulutin, S.; Yardimci, T. (Istanbul)

Suppl. 3

Thromboembolic Diseases: Mechanisms,

Prophylaxis and Treatment. 5th International

Symposium on Thromboembolic Diseases

Cannes, France, June 12-13, 1998

Proceedings

Editors: Kakkar, V.V. (London); Samama, M.M. (Paris)

\section{KARGER}

S. Karger

Medical and Scientific Publishers Basel $\cdot$ Freiburg $\cdot$ Paris $\cdot$ London

New York $\cdot$ New Delhi $\cdot$ Bangkok

Singapore $\cdot$ Tokyo $\cdot$ Sydney
Drug Dosage

The authors and the publisher have exerted every effort to ensure that drug selection and dosage set forth in this text are in accord with current recommendations and practice at the time of publication. However, in view of ongoing research, changes in government regulations, and the constant flow of information relating to drug therapy and drug reactions, the reader is urged to check the package insert for each drug for any change in the package insert for each drug for any change in and precautions. This is particularly importan when the recommended agent is a new and/or infrequently employed drus.
All rights reserved.

No part of this publication may be translated into other languages, reproduced or utilized in any form or by any means, electronic or mechanical, including photocopying, recording, microcopying, or by any information storage and retrieval system, without permission in writing from the publisher or, in the case of photocopying, direct payment of a specified fee to the Copyright Clearance Center (see 'General Information').

(c) Copyright $1998 / 99$ by S. Karger AG, P.O. Box, CH-4009 Basel (Switzerland) Printed in Switzerland on acid-free paper by Reinhardt Druck, Basel 